\title{
Importance of diet in the growth, survivorship and reproduction of the no-tillage pest Armadillidium vulgare (Crustacea: Isopoda)
}

\author{
Importancia de la dieta en el crecimiento, la supervivencia y la reproducción de \\ Armadillidium vulgare (Crustacea: Isopoda) plaga en siembra directa
}

\author{
ARIEL J. FABERI*, ALICIA N. LÓPEZ, NATALIA L. CLEMENTE \& PABLO L. MANETTI
}

Facultad de Ciencias Agrarias, Universidad Nacional de Mar del Plata - Estación Experimental Agropecuaria, Instituto Nacional de Tecnología Agropecuaria (INTA), Ruta 226, km 73.5 C.C. No 276 (7620), Balcarce, Buenos Aires, Argentina

${ }^{*}$ Corresponding author: ajfaberi@hotmail.com

\begin{abstract}
The studies of Armadillidium vulgare as pest are virtually null worldwide. However under no-tillage systems this species has found an adequate environment for its development and it has become an important pest in some crops in Argentina. It has been shown that the composition of vegetables affects the isopods biology. Our hypothesis was that soybean leaf litter has high nutritive value which allows $A$. vulgare to grow faster, survive longer, and have higher fecundity favoring the population increase and turning it into a crop pest. Growth and survivorship of juveniles and adults, egg incubation period, offspring number per female and offspring mean body weight were determined in individuals fed with leaf litter of soybean, sunflower, wheat and pasture. The growth rate coefficient, $\mathrm{k}$, in juveniles was higher for soybean, intermediate for pasture and lower for sunflower. Adult growth was faster under the soybean diet. Survivorship under soybean and pasture was longer than under sunflower and wheat in both juveniles and adults. The reproductive parameters were similar in all diets, food did not generate any change in the reproductive aspects of $A$. vulgare. Results of the present study represent a source of information about the $A$. vulgare biology under different diets of agricultural origin to establish the basis for Integrated Management of this species as pest. Under soybean litter provision A. vulgare found the best conditions for faster growth, longer survival and relatively higher fecundity. In fields with soybean as preceding crop or in systems with high frequency of soybean in the crop rotation a more abundant population of $A$. vulgare would be found as well as with larger individuals which could cause more damage to the following crop in the rotation.
\end{abstract}

Key words: crop leaf litter, food quality, herbivore, N content.

\section{RESUMEN}

Los estudios sobre Armadillidium vulgare como plaga son virtualmente nulos a nivel mundial. Sin embargo, en los sistemas bajo siembra directa esta especie ha encontrado un ambiente adecuado para su desarrollo y se ha convertido en una plaga importante en algunos cultivos en Argentina. Se ha demostrado que la composición de los vegetales afecta la biología de los isópodos. Nuestra hipótesis fue que los residuos vegetales de la soja tienen un valor nutritivo alto lo cual permite a $A$. vulgare crecer más rápido, sobrevivir más y tener una fecundidad elevada favoreciendo el incremento poblacional y convirtiéndolo en plaga de cultivos. El crecimiento y la reproducción de juveniles y adultos, el período de incubación, el número de crías por hembra y el peso medio de las crías fueron determinados en individuos alimentados con residuos de soja, girasol, trigo y pastura. El coeficiente de la tasa de crecimiento, $\mathrm{k}$, en los juveniles fue mayor para la soja, intermedio para la pastura y bajo para el girasol. El crecimiento de los adultos fue mayor con soja. La supervivencia con soja y pastura fue mayor que con girasol y trigo tanto en juveniles como en adultos. Los parámetros reproductivos fueron similares en todas las dietas, el alimento no generó ningún cambio en los aspectos reproductivos de $A$. vulgare. Los resultados del presente estudio representan una fuente de información acerca de la biología de $A$. vulgare con diferentes dietas de origen agrícola, lo que permitirá establecer las bases del Manejo Integrado de esta especie como plaga. Con la provisión de residuos de soja, A. vulgare encontró las mejores condiciones para crecer más rápido, sobrevivir por más tiempo y tener una fecundidad relativamente más elevada. En campos con soja como cultivo antecesor o en sistemas con una frecuencia alta de cultivos de soja en la rotación podría encontrarse una población más abundante y con individuos más grandes de $A$. vulgare los cuales podrían causar mayores daños al cultivo siguiente en la rotación.

Palabras clave: calidad del alimento, contenido de N, herbívoro, residuos de cultivo. 


\section{INTRODUCTION}

In Argentina, as well as in other parts of the world, during the 1970s, an "agriculturization" process has occurred, producing severe soil erosion (Manuel-Navarrete et al. 2005). In response to this problem, farmers have adopted a conservation tillage system such as no-tillage as a soil-protecting measure (Studdert \& Echeverría 2000, García-Préchac et al. 2004). In conservation-tillage systems, litter and soil organic matter tend to concentrate in the upper $5 \mathrm{~cm}$ layer of soil (Dominguez et al. 2005). The litter layer is a very important factor in ameliorating soil temperature and moisture extremes (Cox et al. 1990, Dominguez et al. 2005, Triplett \& Dick 2008), which provides a more stable environment for soil- and litterdwelling invertebrates (Stinner \& House 1990). Thus, under no-tillage systems Armadillidium vulgare (Latreille, 1884) (Crustacea: Isopoda) has found an adequate environment for its development and reproduction and it has become one of the most important pests in soybean, sunflower and oil seed rape crops under that tillage system (Saluso 2004, Mastronardi 2006). Damages are similar to the common no tillage pest, slugs. Glen \& Moens (2002), Moens \& Glen (2002), Faberi et al. (2006) and Salvio et al. (2008) observed that slug damage to plants is caused at sowing and immediately after germination. Similar damages occur with $A$. vulgare, it feeds on seeds and seedlings, causing a reduction in plant density.

Armadillidium vulgare is the most known terrestrial isopod crustacean with a worldwide distribution and is one of the macroscopic invertebrates found in natural and agro ecosystems. Traditionally, it was considered a benefic organism on these ecosystems (Hopkin 1991). The feeding activities of woodlice speed up the decomposition process and help return essential nutrients to the soil (Hopkin 1991, Wolters \& Ekschmitt 1997). This species like other terrestrial isopods is considered a generalist decomposer, feeding mainly on dead plant material (Paris \& Pitelka 1962, Warburg 1993, Wolters \& Ekschmitt 1997, Lavy et al. 2001, Zimmer 2004). In most terrestrial ecosystems, an overwhelming part of the above-ground biomass produced by plants is recycled by the decomposition process of leaf litter caused by saprophagous soil animals and microorganisms (Swift et al. 1979 cited by Zimmer \& Topp 1997).

According to Rushton \& Hassall (1987) the quality of isopod food in the ecosystems shows much variation. Since terrestrial isopods mainly feed on food sources that are considered to be low quality, it is obvious that biological aspects further depend on the available food source (Zimmer \& Topp 2000). Some authors have used different leaf species and diets to examine the influence of leaf litter attributes (e.g., nitrogen $(\mathrm{N})$ content, phenolics, colonizing microbiota, acidity, pH) on isopods (Merrian 1971, Rushton \& Hassall 1983, 1987, Dangerfield 1989, Hassall \& Dangerfield 1990, Zimmer \& Topp 1997, 2000, Kautz et al. 2000, Lavy et al. 2001, Zimmer 2002, 2003, Lardies et al. 2004). These works demonstrated that the vegetable composition affects the isopod biology. However, these works included leaves of species where isopods are common such as forest and natural lands. In agroecosystems of Argentina $A$. vulgare coexists with the most common summer crops, soybean (Glycine max L.), sunflower (Helianthus annuus L.), and maize (Zea mays L.) and with wheat (Triticum aestivum L.) as the winter crop (SAGPyA 2009). The leaf litter of these crops has different composition (e.g., $\mathrm{N}$ content) and soybean is the crop leaf litter with highest $\mathrm{N}$ content (Echeverría et al. 1992, Sánchez et al. 1996). In the extensive literature on the effects of food quality on herbivorous arthropods, dietary nitrogen concentration is used to define food quality (Mattson 1980). For this reason $A$. vulgare population in Argentinean agroecosystems are probably subject to considerable temporal and spatial variation in food quality.

The need for sound ecological information about pests and the crop environment is considered essential for efficient Integrated Pest Management (IPM) program implementation. Pests are broadly under the influence of the total agro ecosystems, and the background knowledge of the role of the principal elements is essential to IPM (Kogan 1998). In Argentina agroecosystems is important to know how agricultural food sources affect the $A$. vulgare biology to establish the basis for Integrated Management of this species as pest. Through in isopods, growth rates determine maturation and fecundity (Merrian 1971, Hassall \& Dangerfield 
1990, Dangerfield \& Hassall 1992) both growth rate and mortality directly influence isopod dynamics, being important from agro ecological point of view with respect to this species as pest. Thus, agro ecological conditions that favor a more abundant population of $A$. vulgare as well as with larger individuals could cause more damage to the crop following in the rotation. The aim of the present work was to evaluate the growth rates, survivorship, and reproductive traits of $A$. vulgare under different food sources of agricultural origin: soybean, sunflower, wheat, and pasture (Festuca arundinacea Schreb. and Trifolium repens L.) leaf litter. It could be predicted that soybean leaf litter has highest nutritive value among the tested food sources, which allows $A$. vulgare to grow faster, survive longer, and have higher fecundity favoring the population increase and turning it into a crop pest.

\section{METHODS}

\section{Animals and diets}

Individuals of $A$. vulgare were obtained from a wild population in a natural field of the Balcarce Agricultural Experimental Station (AES) of National Institute of Agricultural Technology (NIAT) $\left(37^{\circ} 45^{\prime} \mathrm{S}\right.$; $58^{\circ} 18^{\prime} \mathrm{O}$, 120 masl), Argentina. We collected each isopod by hand from leaf litter. The individuals were placed in plastic containers to carry them to the laboratory where they were examined using a stereomicroscope (40X). Specimens were placed ventral side down, and slight pressure was applied dorsally with fine forceps in order to flatten them, care being taken not to cause distortion. Length was determined as the distance from the anterior margin of the cephalotorax to the tip of the telson. Individuals less than $4 \mathrm{~mm}$ in length were considered juveniles and those of $4 \mathrm{~mm}$ or more in length, adults (Paris \& Pitelka 1962). Sex was determined according to Paris \& Pitelka (1962). Females, males and juveniles were kept separately in translucent plastic containers (20 $\mathrm{cm}$ long, $15 \mathrm{~cm}$ wide, and $10 \mathrm{~cm}$ deep, base layer of plaster of Paris) to acclimate them to the chamber condition and to ensure that we had individuals to select those of the same size at the beginning of the different assays. Specimens were acclimated at $18-22{ }^{\circ} \mathrm{C}$ and under photoperiod about 12:12 h (L:D).

Four diets were used and were constituted by leaf litter of the most common crops used in the rotations in Argentina: soybean, sunflower, wheat and an alternative diet, leaf litter of permanent pasture (F. arundinacea and T. repens). Leaf litter was collected at the AES, NIAT; air dried, cut homogeneously (pieces of 5 to $10 \mathrm{~cm}$ ) and stored in a $18-22{ }^{\circ} \mathrm{C}$ chamber until the beginning of the different assays. Nitrogen content was determined by the Kjeldahl method (Bremner \& Mulvaney 1982) at the soil laboratory of the AES, NIAT and they values were $1.32 \%, 0.91 \%, 0.61 \%$ and $0.56 \%$ for pasture, soybean, wheat and sunflower, respectively.

\section{Growth and survivorship of juveniles}

The growth and survivorship of juveniles A. vulgare fed with soybean, sunflower, wheat and pasture were compared from August 2008 to February 2009. Sixty individuals were randomly assigned to each different diet. Individuals were placed in a circular translucent plastic box (9.5 cm in diameter, $6.4 \mathrm{~cm}$ deep) in groups of five (i.e. 12 boxes per diet). The boxes had a bottom layer of damp plaster of Paris and food ad libitum. In the course of experiments, boxes were cleaned, feces were removed, the plaster was rewetted and fresh food was supplied fortnightly.

The containers were maintained in an environmental chamber at $18-22{ }^{\circ} \mathrm{C}$ and under photoperiod about 12:12 h (L:D). During the course of the experiment we counted and discarded dead individuals and weighed the surviving ones individually fortnightly (electronic analytical balance, precision $\pm 0.001 \mathrm{~g}$ ).

In order to describe the growth of juveniles, the mathematical growth model used was the von Bertalanffy (Araujo \& Bond-Buckup 2004, Lardies et al. 2004, Noguera et al. 2008) to fit the weight data of individuals for each diet treatment. The model was:

$$
\mathrm{W}(\mathrm{t})=\mathrm{Wmax}\left(1-\mathrm{B}^{*} \mathrm{e}^{(-\mathrm{k} * \mathrm{t})}\right)^{3}
$$

where $\mathrm{W}(\mathrm{t})$ is the weight as a function of time; Wmax is the asymptotic weight; $\mathrm{k}$ is the parameter related to growth rate, $t$ is the age in days and $B$ is an integration parameter (without biological significance). Growth parameters were estimated with the non lineal mixed models (nlme) procedure of R 2.9.1 (R Development Core Team, 2009). The nlme procedure fits nonlinear mixed models, that is, models in which both fixed and random effects (box) are permitted to have a nonlinear relationship to the response variable.

Two major features of interest in a growth curve are a measurement of growth rate and a measure of maximum body weight. In order to compare growth among each group of individuals, the growth curves obtained for each diet were linearized (Allen 1976):

$$
\mathrm{W}_{\mathrm{i}}(\mathrm{t})=\mathrm{a}-\mathrm{b} * \mathrm{r}^{\mathrm{t}}
$$

where $\mathrm{W}_{\mathrm{i}}(\mathrm{t})$ is the weight estimated for the Bertalanffy growth model as a function of time and $r$ is a constant chosen to give a suitable shape to the growth curves. This parameter was calculated as: $r=e^{-k}$ and we used the average value of $\mathrm{r}\left(\sum \mathrm{e}^{-\mathrm{k}}\right.$ of each diet/number of diets (three diets in the comparison because three growth curves were adjusted: see results)). Because the model is linear in its parameters a and b, standard regression techniques can be used to estimate the parameters a and $\mathrm{b}$ and to test differences between them (Allen 1976). Due to the fact that it is difficult to make comparisons of growth rates when the von Bertalanffy curve is used, in the linear model "age" is given by $\mathrm{r}^{\mathrm{t}}$ and for this curve the growth rate is simply the parameter $b$ and the measure of scale is a = Wmax. The slope (growth rate) and intercept (Wmax) were compared through categorical variables (dummy) (Montgomery et al. 2004) using SAS statistical software (SAS Institute Inc. 2001).

Mortality rates were analyzed in terms of survival fractions at any given time, according to the KaplanMeier method. Subsequent pair-wise comparison of treatments with respect to the individual's risk of mortality was performed according to the Mantel-Haenszel test (Martínez Gonzáles \& Ilara-Estévez 2005) using STATISTICA program (StatSoft Inc. 2005) $(\alpha=0.05)$. 


\section{Growth and survivorship of adults}

To study the growth of adults we evaluated only measurements taken on males, because females show a strong weight variation depending on their reproductive stage (Lardies et al. 2004). Males were identified by the presence of copulation organs, modified endopodites of the first and second pleopods (Paris \& Pitelka 1962).

Four groups of $40 \mathrm{~A}$. vulgare adult individuals were formed and were randomly assigned to each different dietary treatment. From January 2007 until February 2009 they were fed with different leaf litter: soybean, sunflower, wheat and pasture to determine their growth and survivorship. The 40 individuals of each diet were placed in pairs into circular translucent plastic boxes (9.5 $\mathrm{cm}$ in diameter, $6.4 \mathrm{~cm}$ deep, base layer of plaster of Paris) (i.e. 20 boxes per diet) and were maintained in the same chamber and conditions as those of juveniles. During the course of the experiment we counted and discarded dead individuals until we reached $100 \%$ of mortality and weighed the surviving ones individually fortnightly (electronic analytical balance, precision $\pm 0.001 \mathrm{~g}$ ).

The body weight data was fitted to a random coefficient simple regression models for each diet in function of time using PROC MIXED procedure in SAS (SAS Institute Inc. 2001). To evaluate differences in growth rate between diets, the slope of each diet were compared through categorical variables (dummy) (Montgomery et al. 2004) using SAS (SAS Institute Inc. 2001).

Mortality rates were analyzed in terms of survival fractions at any given time, according to the KaplanMeier method. Subsequent pair-wise comparison of treatments with respect to the individual's risk of mortality was performed according to the MantelHaenszel test (Martínez Gonzáles \& Ilara-Estévez 2005) using STATISTICA program (StatSoft Inc. 2005).

\section{Reproduction}

Reproductive parameters of $A$. vulgare were compared for the four food regimens (i.e. soybean, sunflower, wheat and pasture leaf litter). In a circular translucent plastic box $(9.5 \mathrm{~cm}$ in diameter, $6.4 \mathrm{~cm}$ deep, base layer of plaster of Paris) two females and one male were placed and food was supplied ad libitum. We placed females and males together to allow fertilization and egg extrusion in the females. We utilized 20 replicate plastic boxes for each diet (i.e. 60 individuals, 40 females and 20 males per diet). The selected females had on average the similar size at the beginning of the assay in each group (i.e. 40 to $50 \mathrm{mg}$ of body weight). Boxes were maintained in an environmental chamber at $18-22{ }^{\circ} \mathrm{C}$ and under photoperiod about $12: 12 \mathrm{~h}$ (L:D). The boxes were cleaned, the plaster was rewetted and fresh food was supplied fortnightly.

Individuals were examined daily to determine the moment of egg extrusion into the brood pouch. This moment was denoted by the change in coloration in the anterior ventral zone. At this moment we separated the females and placed them in individual plastic boxes until the day of the offspring release, for which we assessed the females daily. The number of juveniles (mancae) released were counted and weighed together in an electronic analytical balance (precision $\pm 0.001 \mathrm{~g}$ ).

We measured the following reproductive parameters: egg incubation period (IP), offspring number per female $(\mathrm{ON})$ and mean body weight of the offspring (BW). To test for differences in the reproductive trails between four diet treatments we performed one-way ANOVA using SAS (SAS Institute Inc. 2001). For all statistical analyses, a significance level of $\alpha=0.05$ was applied.
RESULTS

\section{Growth and survivorship of juveniles}

There were significant differences between growth models with fixed effects and random effects four each food source $(\mathrm{P}<0.001)$. Therefore, we choose growth models with random effects for all diets. The weight data in the juvenile stage fitted the von Bertalanffy growth model in individuals fed with soybean $\left(\mathrm{F}_{5,646}=646.35, \mathrm{P}<0.0001\right.$, Fig. $\left.1 \mathrm{~A}\right)$, sunflower $\left(\mathrm{F}_{5,437}=539.71, \mathrm{P}<0.0001\right.$, Fig. 1C) and pasture $\left(\mathrm{F}_{5,534}=612.12, \mathrm{P}<0.0001\right.$, Fig. 1D $)$. No model fitted well in specimens fed with wheat. However individuals fed with wheat showed a relatively lower weight than the ones fed with the other diets (Fig. 1B). There was variation in asympotic weight and growth rate coefficient, $\mathrm{k}$, among boxes in individuals feed with soybean $\left(\mathrm{SD}_{\mathrm{Wmax}}=4.151 \mathrm{mg}\right.$ and $\left.\mathrm{SD}_{\mathrm{k}}=0.013\right)$, sunflower $\left(\mathrm{SD}_{\mathrm{Wmax}}=5.174 \mathrm{mg}\right.$ and $\left.\mathrm{SD}_{\mathrm{k}}=0.015\right)$, and pasture $\left(\mathrm{SD}_{\mathrm{Wmax}}=4.433 \mathrm{mg}\right.$ and $\left.\mathrm{SD}_{\mathrm{k}}=0.007\right)$.

The growth rate coefficient, $\mathrm{k}$, varied between 0.0355 for sunflower to 0.0449 for soybean, with intermediate value for pasture (0.0428). However the maximum weight (asymptotic weight, Wmax) reached with soybean and sunflower was higher than that reached with pasture. Fig. 2 shows the linearized growth curves (Allen 1976), where significant differences were observed between slopes of pasture and soybean (Regression analysis, $\left.\mathrm{F}_{1,24}=8.92, \mathrm{P}=0.006\right)$, pasture and sunflower (Regression analysis, $\mathrm{F}_{1,24}=16.72$, $\mathrm{P}=0.0004)$ and soybean and sunflower did not have significant differences (Regression analysis, $\left.\mathrm{F}_{1,24}=6.41, \mathrm{P}=0.018\right)$. We also found a similar pattern of differences for the intercept (soybean-sunflower: $\mathrm{F}_{1,24}=25.18, \mathrm{P}<0.001$; soybean-pasture: $\mathrm{F}_{1,24}=94.90, \mathrm{P}<0.001$; and sunflower-pasture: $\mathrm{F}_{1,24}=102.09, \mathrm{P}<0.001$ ).

In general survivorship was similar in the four groups in the first 30 days of study. Statistical analysis showed that survivorship observed in soybean and pasture groups was higher than that observed in wheat group (Mantel-Haenszel test, $\mathrm{P}=0.03$, and $\mathrm{P}=0.0001$, respectively). Significant differences were observed between pasture and sunflower diets (Mantel-Haenszel test, $\mathrm{P}=0.001$ ) (Fig. 3) but not differences were observed between soybean and sunflower (Mantel-Haenszel test, $\mathrm{P}=0.29$ ). 


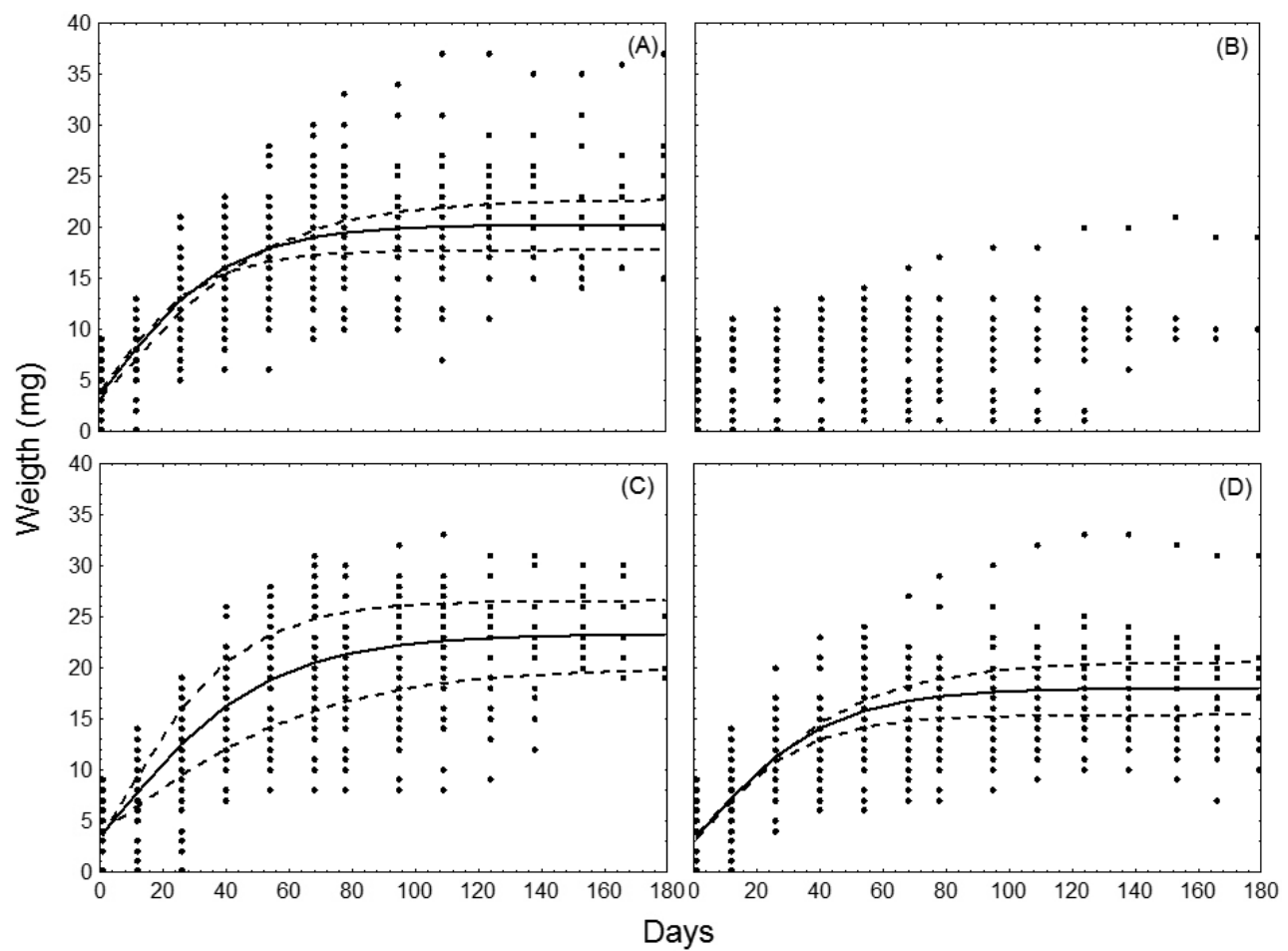

Fig. 1: Growth curves of juvenile Armadillidium vulgare fed with leaf litter of soybean $(\mathrm{A})[\mathrm{W}=20.2542$

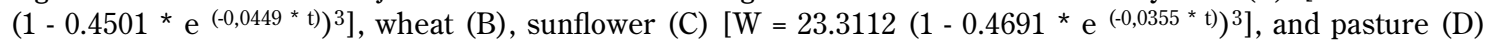
$\left[\mathrm{W}=18.0076\left(1-0.4381 * \mathrm{e}^{(-0,0428 * \mathrm{t})}\right)^{3}\right]$. Full line: von Bertalanffy growth model. Dotted lines: $95 \%$ confidence interval of the model.

Curvas de crecimiento de juveniles de Armadillidium vulgare alimentados con residuos vegetales de soja (A) $[\mathrm{W}=20.2542(1-0.4501$ * $\left.\left.\mathrm{e}^{\left(-0,044{ }^{*} \mathrm{t}\right)}\right)^{3}\right]$, trigo $(\mathrm{B})$, girasol $(\mathrm{C})\left[\mathrm{W}=23.3112\left(1-0.4691{ }^{*} \mathrm{e}^{\left(-0,0355^{*} \mathrm{t}\right)}\right)^{3}\right]$ y pastura (D) $\left[\mathrm{W}=18.0076\left(1-0.4381{ }^{*} \mathrm{e}^{\left(-0,0428^{*} \mathrm{t}\right)}\right)^{3}\right]$. Línea continua: modelo de crecimiento de von Bertalanffy. Líneas punteadas: intervalo del $95 \%$ de confianza del modelo.

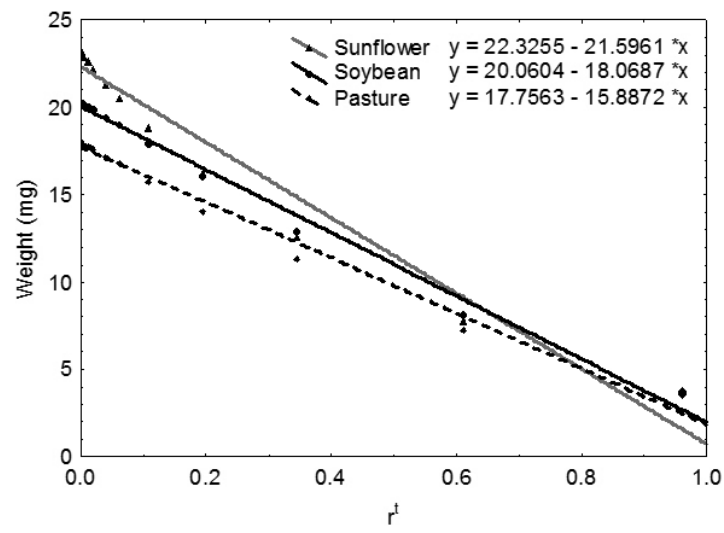

Fig. 2: Linearized regressions (Allen method [1976]) of the weight of juvenile Armadillidium vulgare fed with leaf litter of soybean, sunflower and pasture in relation to transformed age $\left(\mathrm{r}^{\mathrm{t}}\right)$.

Regresiones linealizadas (Método de Allen [1976]) del peso de juveniles de Armadillidium vulgare alimentados con residuos vegetales de soja, girasol y pastura en relación a la edad trasformada $\left(\mathrm{r}^{\mathrm{t}}\right)$.

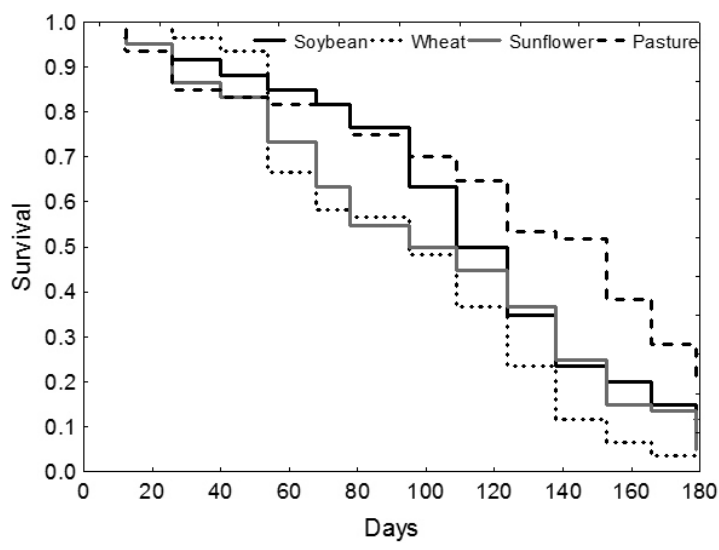

Fig. 3: Mortality (Kaplan-Meier method) of juvenile Armadillidium vulgare feeding on leaf litter of soybean, wheat, sunflower and pasture during development.

Mortalidad (método de Kaplan-Meier) de juveniles de Armadillidium vulgare alimentados con residuos vegetales de soja, trigo, girasol y pastura durante el desarrollo. 


\section{Growth and survivorship of adults}

The growth obtained for individuals fed with soybean, sunflower, wheat and pasture are shown in Figs. 4A, 4B, 4C and 4D, respectively. Body weight was fitted in function of time to simple regression in individuals fed with soybean $\left(\mathrm{F}_{1,19}=183.16, \mathrm{P}<0.001\right)$, sunflower $\left(\mathrm{F}_{1,19}=\right.$ 103.80, $\mathrm{P}<0.001)$, pasture $\left(\mathrm{F}_{1,18}=134.32, \mathrm{P}<\right.$ $0.001)$ and with wheat $\left(\mathrm{F}_{1,19}=12.32, \mathrm{P}<0.002\right)$.

We found no differences for body weight at the beginning of the experiment among dietary treatments (ANOVA, $\mathrm{F}_{3,140}=3.28, \mathrm{P}=0.234$ ). Analysis of adult males revealed that growth rate was different for individuals fed with different diets. The growth rate of individuals fed with soybean was higher than those observed for sunflower, pasture and wheat (Regression analysis, $\mathrm{F}_{1,1349}=4.19, \mathrm{P}=0.041$; $\mathrm{F}_{1,1578}=17.85, \mathrm{P}<0.001 ; \mathrm{F}_{1,1271}=25.81, \mathrm{P}<$ 0.001 , respectively). The growth rate for wheat was lower than those achieved with sunflower and pasture (Regression analysis, $\mathrm{F}_{1,774}=10.72$, $\left.\mathrm{P}=0.001 ; \mathrm{F}_{1,1003}=3.91, \mathrm{P}=0.048\right)$. Sunflower and pasture have an intermediate growth rate, but these were slightly different (Regression analysis, $\mathrm{F}_{1,1081}=3.86, \mathrm{P}=0.049$ ).

The survivorship of adults of $A$. vulgare was similar with soybean and pasture (MantelHaenszel test, $\mathrm{P}=0.47$ ) and with sunflower and wheat (Mantel-Haenszel test, $\mathrm{P}=0.36$ ) (Fig. 5). Survival of the populations fed with wheat was lower than those fed with soybean (Mantel-Haenszel test, $\mathrm{P}<0.0001$ ) and pasture (Mantel-Haenszel test, $\mathrm{P}=0.02$ ). The same occurred with sunflower respect to soybean (Mantel-Haenszel test, $\mathrm{P}=0.0004$ ) and pasture (Mantel-Haenszel test, $\mathrm{P}=0.06$ ). The $100 \%$ of dead individuals was reached at day 414 with wheat, and at day 596 with sunflower. Mortality of all individuals was reached at day 760 with soybean and pasture (Fig. 5).

\section{Reproduction}

The reproduction parameters analyzed in this work are shown in Table 1. The parameters were similar in all food regimens, hence food not did generate any change in the reproductive trails of $A$. vulgare. As not all females formed the brood pouch, the reproductive aspects were determined in a variable number of individuals (Table 1).
The IP did not differ significantly among treatments (ANOVA, $\mathrm{F}_{3,26}=0.63, \mathrm{P}=0.602$ ). The $\mathrm{ON}$ of $A$. vulgare was between 25 to 96 individuals per female. While with soybean, females had a slightly mean ON, it did not differ significantly to the other groups (ANOVA, $\mathrm{F}_{3,25}$ $=1.038, \mathrm{P}=0.393)$. The feeding crop litter in this study did not originate any change in the offspring BW (ANOVA, $\mathrm{F}_{3,25}=1.497, \mathrm{P}=0.241$ ).

\section{DISCUSSION}

Results of this study indicated that life history parameters of $A$. vulgare were significantly influenced by leaf litter food supply. Several studies have documented the influence of food quality on growth of isopods. According to Merriam (1971) the most important effect of food is the change in the growth rate of individuals. The author found that adult $A$. vulgare grew faster under on diets with high protein content (high quality). Similar results were found with the isopod Oniscus asellus (L.

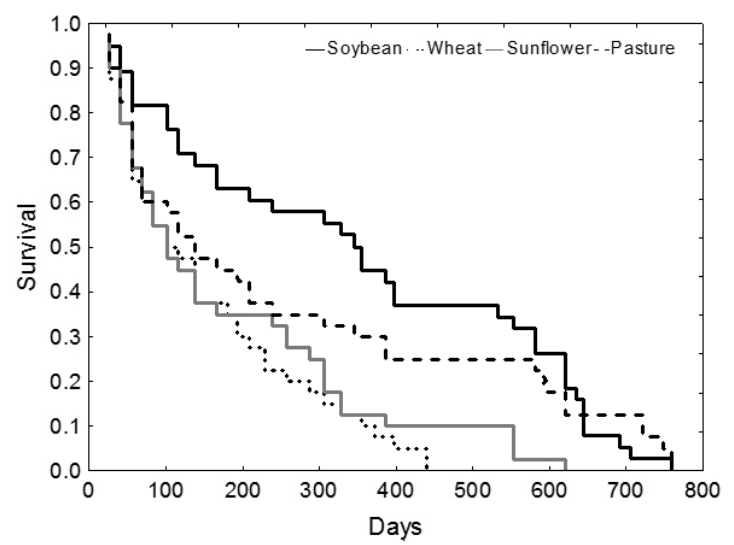

Fig. 4: Growth of adult Armadillidium vulgare fed with leaf litter of soybean (A) $[\mathrm{W}=43.025+0.177 \mathrm{t}]$, wheat (B) $[\mathrm{W}=37.082+0.060 \mathrm{t}]$, sunflower (C) $[\mathrm{W}=40.641+0.136 \mathrm{t}]$, and pasture (D) $[\mathrm{W}=41.760+$ $0.103 \mathrm{t}]$. Full line: growth lineal model, Dotted lines: $95 \%$ confidence interval of the model. W: weight (mg), t: time (days).

Crecimiento de adultos de Armadillidium vulgare alimentados con residuos vegetales de soja (A) $\mathrm{W}=$ $43.025+0.177 \mathrm{t}]$, trigo (B) $[\mathrm{W}=37.082+0.060 \mathrm{t}]$, girasol (C) $[\mathrm{W}=40.641+0.136 \mathrm{t}]$ y pastura (D) $[\mathrm{W}=41.760+$ $0.103 t$ ]. Línea continua: modelo de crecimiento lineal, línea punteada: intervalo del $95 \%$ de confianza del modelo. W: Peso (mg), t: tiempo (días). 
1758) where the weight of the individuals fed on high $\mathrm{N}$ content food increased significantly more than that of individuals fed on low $\mathrm{N}$ food (Lavy et al. 2001). On the contrary, in Porcelio scaber (Latreille 1804) (Lavy et al. 2001) and in A. vulgare (Rushton \& Hassall 1983) it has been found no differences in growth of individuals fed with different $\mathrm{N}$ content diets. However, both species prefer food with high $\mathrm{N}$ content (Szlavecz \& Maiorana 1990). On the other hand, isopods have behavioural skills associated with diet selection and physiological flexibility that may allow them to satisfy and maintaining equivalent nutritional levels during exposure to

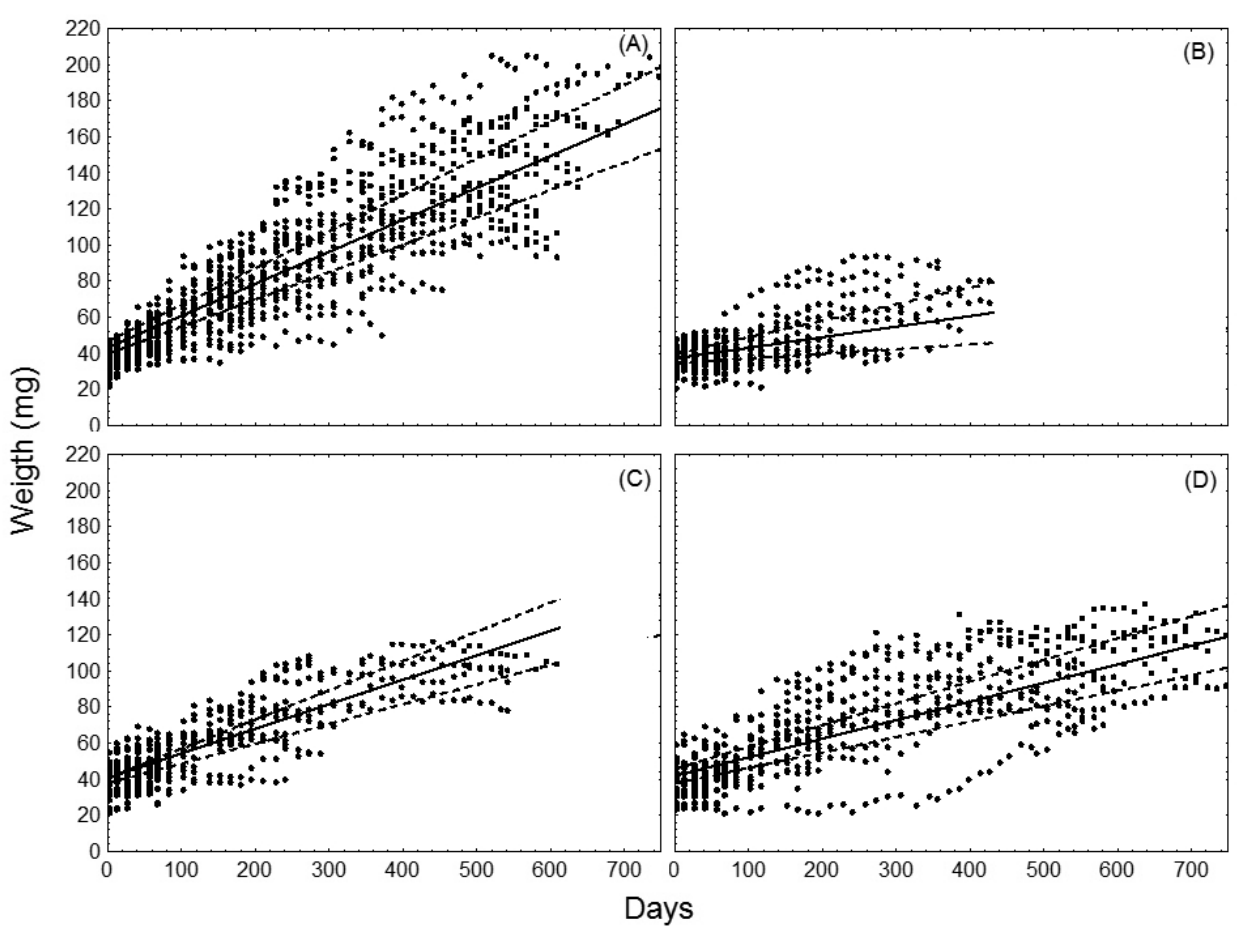

Fig. 5: Mortality (Kaplan-Meier method) of adult Armadillidium vulgare feeding on leaf litter of soybean, wheat, sunflower and pasture during development.

Mortalidad (método de Kaplan-Meier) de adultos de Armadillidium vulgare alimentados con residuos vegetales de soja, trigo, girasol y pastura durante el desarrollo.

TABLE 1

Mean values $( \pm \mathrm{SD})$ of incubation period, number of juveniles and body weight of the offspring of Armadillidium vulgare feed with leaf litter of soybean, sunflower, wheat and pasture.

Valores promedio $( \pm \mathrm{DE})$ del periodo de incubación, número de juveniles, peso corporal de la progenie de Armadillidium vulgare alimentados con residuos vegetales de soja, girasol, trigo y pastura.

\begin{tabular}{lcccc}
\hline Diet & $\begin{array}{c}\text { Number of } \\
\text { females }\end{array}$ & $\begin{array}{c}\text { Incubation period } \\
\text { (days) }\end{array}$ & $\begin{array}{c}\text { Number of juveniles per } \\
\text { female }\end{array}$ & $\begin{array}{c}\text { Body weight of the } \\
\text { offspring (mg) }\end{array}$ \\
\hline Soybean & 7 & $27.0(7.69)$ & $66.6(22.95)$ & $0.252(0.076)$ \\
Sunflower & 13 & $27.7(0.57)$ & $55.3(19.42)$ & $0.258(0.038)$ \\
Wheat & 3 & $27.5(5.89)$ & $50.7(20.44)$ & $0.280(0.051)$ \\
Pasture & 6 & $31.5(7.94)$ & $54.7(8.71)$ & $0.315(0.050)$ \\
\hline
\end{tabular}


different diet qualities. Isopods may respond to spatial and temporal changes in the qualitative availability of food by varying their feeding tactics, i.e., by increasing their consumption rates when food does not match their nutritional requirements. For instance, Catalán et al. (2008) and Abelho et al. (2009) reported that isopods tended to consume more tissue per unit body mass of the high $\mathrm{C}: \mathrm{N}$ ratio diets, probably as a way of compensating the N-poor food through increased consumption.

In our study while the growth rate of adult A. vulgare depended on the diet, growth was not associated with the $\mathrm{N}$ content of food. In diets with high $\mathrm{N}$ content, soybean and pasture (0.91 and $1.32 \%$, respectively) growth was different, it was higher with soybean and lower with pasture. Moreover, with sunflower (diets with low $\mathrm{N}$ content, $0.56 \%$ growth was higher than that of individuals fed with pasture and with wheat $(\mathrm{N}$ content $=0.62 \%)$. In this vein, several other variables are recognized as the responsible for food quality. For example, Zimmer \& Topp (2000) found that $P$. scaber and $O$. asellus performed better (in terms of growth, reproduction and mortality) on litter with low $\mathrm{C}: \mathrm{N}$ ratio, relatively high $\mathrm{pH}$ levels, and low phenolic contents. In general it is believed that the $\mathrm{N}$ availability in the intestine is the determinant factor for food quality (Rushton $\&$ Hassall 1983). In this sense litter-colonizing microbiota provides an accessible $\mathrm{N}$ source (Zimmer \& Topp 2000). We hypothesize that those variables may be responsible for the differences in adults growth observed in our work with different crop leaf litter.

In juveniles we found that growth was associated with the $\mathrm{N}$ content of the diet. The coefficient of growth rate, $\mathrm{k}$, was higher for pasture ( $\mathrm{N}$ content $1.32 \%)$, and soybean ( $\mathrm{N}$ content $0.91 \%)$ and lower for sunflower (N content $0.56 \%)$. Similar results have been observed in juveniles of $P$. laevis (Latreille, 1804) which grew faster under high $\mathrm{N}$ content diets (Lardies et al. 2004). The growth rate of juvenile $A$. vulgare increased exponentially with the increasing proportion of high-quality food (Dicotyledonous) in the diet. On the other hand, Monocotyledonous species represent a low quality diet for that isopod species (Rushton \& Hassall 1987). In crustaceans the total dietary protein requirement is typically higher for young, rapidly growing animals than for adults, due to the need for fast tissue synthesis (Lardies et al. 2004).

There are at least three important consequences when isopods growth in optimal conditions. Merrian (1971) and Rushton \& Hassall (1983) demonstrated that food quality can significantly change $A$. vulgare growth rate, directly affecting the age at the first reproduction, which is a key factor in controlling the population growth. A second factor is manifested through increases in the offspring number released from females. Fecundity increases with the size of female of A. vulgare (Paris \& Pitelka 1962), for that reason bigger females release more juveniles. A third aspect is related to the ability to produce damage on crops. Bigger individuals are able to produce more damages in soybean (Saluso 2004) and sunflower crops (Faberi et al. 2010¹). Our study demonstrated that soybean leaf litter allows $A$. vulgare to grow faster exposing crops to a more abundant and potentially more harmful population of this species.

Survival seems to be associated with the $\mathrm{N}$ content of the diet in both juveniles and adults of $A$. vulgare. In fact, it was relatively shorter in animals fed with sunflower and wheat (lower $\mathrm{N}$ content) compared with those fed with soybean and pasture (higher $\mathrm{N}$ content). In juvenile $A$. vulgare survival is higher as the percentage of high quality food in the diet increases (Rushton \& Hassall 1987). In juveniles of other isopod species the diet has an effect on their survivorship, O. asellus (Zimmer \& Topp 2000), P. scaber (Zimmer 2002) and Trichoniscus pusillus (Brandt 1833) (Kautz et al. 2000) survive shorter with low quality food (high C:N ratio). Similar results were reported in adults of A. vulgare by Merriam (1971) and in P. scaber y O. asellus by Zimmer (2002). In this sense, it has been reported that Monocotyledonous species cause more mortality in adults of $A$. vulgare than Dicotyledonous species (Rushton \& Hassall 1983, 1987). Similarly survivorship is higher when the proportion of Dicotyledonous in a natural pasture is high (Hassall \& Dangerfield

FABERI AJ, AN LÓPEZ, PL MANETTI \& NL CLEMENTE (2010) Severidad de los daños ocasionados por Armadillidium vulgare (Crustacea: Isopoda) de diferentes tamaños corporales en el cultivo de girasol. Taller ASAGIR 2010, March 2010. Mar del Plata. Argentina. 
1990). In the same way, soybean leaf litter allows a longer survivorship of $A$. vulgare individuals which could cause more damages on crops.

The IP was in general shorter than those previously published. Heeley (1942) reported that under controlled conditions the IP is 42 days but the temperature of study was not mentioned. On the other hand, in natural conditions the developmental period from oviposition to release of young is 40 to 50 days with a mean temperature of $15.7{ }^{\circ} \mathrm{C}$ (AlDabbagh \& Block 1981). In our study, the mean temperature was $20{ }^{\circ} \mathrm{C}$ which could have caused a faster offspring development. In contrast with our results, in $P$. laevis the IP is different between different $\mathrm{N}$ contents in the diet (Lardies et al. 2004). These authors found that the IP is significantly shorter for the high concentration diet group.

The published data about the number of juveniles produced per brood by $A$. vulgare females is quite variable. Paris \& Pitelka (1962) cited values between 5 to 175 young per female. Undoubtedly much of this variation is related to differences in the size of the female. There is a significant positive correlation between young number and female size (Paris \& Pitelka 1962). In our experiment all females had the similar mean body weight and this effect could not be evaluated. Rushton \& Hassall (1983) found that A. vulgare females fed with Dicotyledonous species are able to produce more quantity of progeny. In other isopods, differences were observed in young number produced per female under different N content diets (Kautz et al. 2000, Lardies et al. 2004). When there is temporal heterogeneity in environmental conditions (e.g., food quality), changes in patterns of resource allocation may result from phenotypic plasticity. Theory predicts that phenotypic plasticity in a trait will be of selective advantage under variable environmental conditions (Hassall et al. 2005). These authors found that $A$. vulgare have different resources allocation to reproductive traits in response to changes in food quality. Overall allocation to reproduction increased when the quality of food improved (i.e. dicotyledonous leaves), due primary to an increase in the number of offspring (Hassall et al. 2005). While with soybean the ON per $A$. vulgare female was relatively higher, no relation was observed with diet $\mathrm{N}$ content in the present experiment condition. The phenotypic plasticity in Argentinean $A$. vulgare populations needs further research.

Maternal diet influences young size in many arthropods (Fox \& Czesak 2000). In crustacean isopods females produce larger progeny at low food concentration (Brody \& Lawlor 1984). Lardies et al. (2004) found that the smallest offspring are obtained from females fed with high protein diets. The authors suggested that the negative correlation between offspring number and offspring size in high protein diets indicates that carbohydrates are the limiting essential nutrient. Carbohydrates play a critical role in the production of glucosamine, which is the precursor in the synthesis of chitin, the principal constituent of crustacean exoskeletons (Harrison 1990). In our study such association was not observed as offspring size (BW) was the same in each group evaluated. In consequence, in each crop leaf litter group $A$. vulgare attained to produce offspring of the same size.

In short, respect to the reproductive parameters, there was not great variability between diets. Soybean, sunflower, wheat and pasture leaf litter allowed $A$. vulgare to reproduce normally apparently with no limitation. Ganter (1984) found some densitydependent effects on growth, survivorship and reproduction of $A$. vulgare. High density, reduced growth rate, survivorship and alters the reproduction of the specie. However, the author use higher densities in his study, so in our study effects of density on isopod are not expected.

Studies of $A$. vulgare as pest are virtually null worldwide. There is information regarded the biology of isopods under different food conditions, basically leaf litter from forests and natural land species. The present study represents a source of information on the A. vulgare biology under different diets of agricultural origin. We concluded that the biology of this species differ under different food conditions in agricultural systems. However, it is difficult to define which dietary features determine the quality of food. As mentioned, most studies refer to food quality as the $\mathrm{N}$ content, but in our study diet quality were only related partly to the $\mathrm{N}$ quantity in food. To establish which specific characteristics of the diet affects the biological performance of $A$. vulgare requires further study. Even if traits to determine food quality 
are still unknown, some general agricultural suggestions could be taken into account to establish the basis for Integrated Management of this species as pest. Under soybean litter provision $A$. vulgare found the best conditions for faster growth, longer survival and relatively higher fecundity. Consequently, in fields with soybean as preceding crop or in systems with high frequency of soybean in the crop rotation a more abundant population of A. vulgare would be found as well as with larger individuals. Both of these aspects, abundance and size, could cause more damage to the crop following in the rotation. The incorporation of Monocotyledonous species, such as wheat, could ameliorate the isopod population increase. While further studies under natural conditions are still necessary, rotation seems to be good resource in the Integrated Management of $A$. vulgare.

ACKNOWLEDGMENTS: We want to express our gratitude to Dr. Paula Araujo for her help in our work. We thank Claudia Pascali for comments on the manuscript and help with our English. This work was financially supported by a project No 15/A 267/08 National University of Mar del Plata, Argentina.

\section{LITERATURE CITED}

ABELHO M \& JR MC MOLLES (2009) Effect of introduced exotic tree litter on consumption patterns of the introduced exotic isopod Armadillidium vulgare. European Journal of Soil Biology 45: 306-311.

AL-DABBAGH KY \& W BLOCK (1981) Population ecology of a terrestrial isopod in two Breckland grasss heaths. Journal of Animal Ecology 50: 61-77.

ALLEN RL (1976) Method for comparing fish growth curves. New Zealand Journal of Marine and Freshwater Research 10: 687-692.

ARAUJO PB \& G BOND-BUCKUP (2004) Growth curve of Atlontoscia floridiana (van Name) (Crustacea, Isopoda, Philosciidae) from a Brazilian Restina Forest. Revista Brasileira de Zoologia 21: 1-8.

BREMNER JM \& C MULVANEY (1982) Nitrogen total. In: Page AL, RH Miller \& DR Keeney (eds) Methods of soil analysis: 595-624. Part 2. Agronomic Monograph. ASA and SSSA, Madison, Wisconsin, USA.

BRODY MS \& LR LAWLOR (1984) Adaptive variation in offspring size in a terrestrial isopod, Armadillidium vulgare. Oecologia 61: 55-59.

CATALÁN TP, MA LARDIES \& F BOZINOVIC (2008) Food selection and nutritional ecology of woodlices in central Chile and its ecological implications. Physiological Entomology 33: 89-94.

COX WJ, RW ZOBEL, HM VAN ES \& DJ OTIS (1990) Tillage effects on some soil physical and corn physiological characteristics. Agronomy Journal 82: 806-812.
DANGERFIELD MJ (1989) Competition and the effects of density on terrestrial isopods. Monitore Zoologia Italiana 4: 411-423.

DANGERFIELD MJ \& M HASSALL (1992) Phenotypic variation in the breeding phenology of the woodlouse Armadillidium vulgare. Oecologia 89: 140-146.

DOMÍNGUEZ GF, GA STUDDERT \& HE ECHEVERRÍA (2005) Propiedades del suelo: Efectos de las prácticas de manejo. In: Echeverría $\mathrm{HE} \& \mathrm{FO}$ García (eds) Fertilidad de suelos y fertilización de cultivos: 207-229. Ediciones INTA, Balcarce, Argentina.

ECHEVERRÍA HE, CA NAVARRO \& FH ANDRADE (1992) Nitrogen nutrition of wheat following different crops. Journal of Agricultural Science of Cambridge 118: 157-163.

FABERI AJ, AN LÓPEZ, PL MANETTI, NL CLEMENTE \& HA ÁLVAREZ-CASTILLO (2006) Growth and reproduction of the slug Deroceras laeve (Müller) (Pulmonata: Stylommatophora) under controlled conditions. Spanish Journal of Agricultural Research. 4: 345-350.

FOX CH \& ME CZESAK (2000) Evolutionary ecology of progeny size in arthropods. Annual Review of Entomology 45: 341-369.

GANTER PF (1984) The effects of crowding on terrestrial isopods. Ecology 65: 438-445.

GARCÍA-PRÉCHAC F, O ERNST, G SIRI-PRIETO \& JA TERRA (2004) Integrating no-till into crop-pasture rotations in Uruguay. Soil and Tillage Research 77: $1-13$.

GLEN DM \& R MOENS (2002) Agriolimacidae, Arionidae and Milacidae as pests in west European cereals. In: Barker GM (ed) Molluscs as crop pests: 271-300. CABI Publishing, Wallingford, UK.

HARRISON KE (1990) The role of nutrition in maturation, reproduction and embryonic development of decapods crustacean: A review. Journal of Shell Research 9: 1-28.

HASSALL M \& JM DANGERFIELD (1990) Densitydependent processes in the population dynamics of Armadillidium vulgare (Isopoda: Oniscidae). Journal of Animal Ecology 59: 941-958.

HASSALL M, A HELDEN, A GOLDSON \& A GRANT (2005) Ecotypic differentiation and phenotypic plasticity in reproductive traits of Armadillidium vulgare (Isopoda: Oniscidea). Oecologia 143: 51-60.

HEELEY W (1942) The habits and life-histories of woodlice. Essex Naturalist 27: 139-149.

HOPKIN S (1991) A key to the woodlice of Britain and Ireland. Field Studies Council. London, UK.

KAUTZ G, M ZIMMER \& W TOPP (2000) Responses of the parthenogenetic isopod, Trichoniscus pusillus (Isopoda: Oniscidea), to changes in food quality. Pedobiologia 44: 75-85.

KOGAN M (1998) Integrated pest management: Historical perspectives and contemporary developments. Annual Review of Entomology 43: 243-270.

LARDIES MA, MJ CARTER \& F BOZINOVIC (2004) Dietary effects on life history traits in a terrestrial isopod: The importance of evaluating maternal effects and trade-offs. Oecologia 138: 387-395.

LAVY D, MJ VAN RIJN, HR ZOOMER \& HA VERHOEF (2001) Dietary effects on growth, reproduction, body composition and stress resistance in the terrestrial isopods Oniscus asellus and Porcellio scaber. Physiological Entomology 26: 18-25. 
MANUEL-NAVARRETE D, G GALLOPÍN, M BLANCO, M DÍAZ-ZORITA, D FERRARO, et al. (2005) Análisis sistémico de la agriculturización en la pampa húmeda argentina y sus consecuencias en regiones extrapampeanas: Sostenibilidad, brechas de conocimiento e integración de políticas. CEPAL - SERIE Medio ambiente y desarrollo. Naciones Unidas. Chile.

MASTRONARDI F (2006) Control químico de isópodos y babosas en un cultivo de girasol bajo siembra directa. Grade Thesis, Facultad de Ciencias Agrarias, Universidad Nacional de Mar del Plata.

MATTSON WJ (1980) Herbivory in relation to plant nitrogen content. Annual Review of Ecology and Systematics 11: 119-161.

MERRIAN HG (1971) Sensitivity of terrestrial isopod populations (Armadillidium) to food quality differences. Canadian Journal of Zoology 49: 667674.

MARTÍNEZ GONZALES MA \& J ILARA-ESTÉVEZ (2005) Análisis de supervivencia y análisis multivariado $21 \mathrm{pp}$. (on line) URL: http://www. catedras.fsoc.uba.ar/salvia/programa/Analisis_ supervivencia_multivariado.pdf (accessed January $21,2010)$.

MOENS R \& DM GLEN (2002) Agriolimacidae, Arionidae and Milacidae as pests in west European oilseed rape. In: Barker GM (ed) Molluscs as crop pests: 425-439. CABI Publishing, Wallingford, UK.

MONTGOMERY DC, EA PECK \& GG VINING (2004) Introducción al análisis de regresión lineal. Compañía Editorial Continental, México DF, México.

NOGUERA RR, RL PEREIRA \& CE SOLARTE (2008) Comparación de modelos no lineales para describir curvas de crecimiento en cuyes (Cavia porcellus) desde el nacimiento hasta la edad de sacrificio. Livestock Research for Rural Development (on line) URL: http://www.lrrd. org/lrrd20/5/nogu20079.htm (accessed March $8,2009)$.

PARIS OH \& FA PITELKA (1962) Population characteristics of the terrestrial isopod Armadillidium vulgare in California grassland. Ecology 43: 229-248.

R DEVELOPMENT CORE TEAM (2009) R: A language and environment for statistical computing. $\mathrm{R}$ Fundation for Statistical Computing, Viena, Austria. URL: http://www.R-project.org (accessed May 2, 2009).

RUSHTON SP \& M HASSALL (1983) Food and feeding rates of the terrestrial isopod (Armadillidium vulgare) (Latreille). Oecologia 57: 415-419.

RUSHTON SP \& M HASSALL (1987) Effects of food quality on isopod population dynamics. Functional Ecology 1: 359-367.

SAGPyA (2009) Secretaría de Agricultura, Ganadería, Pesca y Alimentación. Estimaciones agrícolas. URL: http://www.sagpya.mecon.gov.ar/ (accessed June 1, 2009).

SALUSO A (2004) Determinación del nivel de daño económico y plan de decisión secuencial para el manejo de Armadillidium vulgare (Latreille, 1804)
(Crustacea: Isopoda) en soja. Master Thesis, Departamento Académico de Ciencias Aplicadas a la Producción al Ambiente y el Urbanismo, Universidad de La Rioja.

SALVIO C, AJ FABERI, AN LÓPEZ, PL MANETTI \& NL CLEMENTE (2008) The efficacy of three metaldehyde pellets marketed in Argentina, on the control of Deroceras reticulatum (Müller) (Pulmonata: Stylommatophora). Spanish Journal of Agricultural Research. 6: 70-77.

SÁNCHEZ SR, GA STUDDERT \& HE ECHEVERRÍA (1996) Descomposición de residuos de cosecha en un Argiudol típico. Ciencia del Suelo (Argentina) 14: 63-68.

SAS INSTITUTE (2001) SAS/STAT software release 8.02. SAS Institute Inc., Cary, USA.

STATSOFT INC (2005) STATISTICA (data analysis software system). [CD-ROM] version 7.1.

STINNER BR \& GJ HOUSE (1990) Arthopods and other invertebrates in conservation-tillage agriculture. Annual Review of Entomology 35: 299-318.

STUDDERT GA \& HE ECHEVERRÍA (2000) Crop rotations and nitrogen fertilization to manage soil organic carbon dynamics. Soil Science Society of America Journal 64: 1496-1503.

SZLAVECZ K \& VC MAIORANA (1990) Food selection by isopods in paired choice tests. Proceedings Third Symposium on the Biology of Terrestrial Isopods: 115-121. Poitiers, France.

TRIPLETT GB \& WA DICK (2008) No-tillage crop production: A revolution in agriculture! Agronomy Journal 100: S153-S165.

WARBURG MR (1993) Evolutionary biology of land isopods. Springer-Verlag Berlin Heidelberg, Germany.

WOLTERS V \& K EKSCHMITT (1997) Gastropods, isopods, diplopos, chilopods: Neglected groups of the decomposer food web. In: Benckiser G (ed) Fauna in soil ecosystems: 265-306. Recycling processes, nutrient fluxes, and agricultural production. Marcel Dekker Inc., New York, USA.

ZIMMER M (2002) Postembryonic ontogenetic development in Porcellio scaber (Isopoda: Oniscidea): The significance of food. Invertebrate Reproduction and Development 42: 75-82.

ZIMMER M (2003) Habitat and resource use by terrestrial isopods (Isopoda, Oniscidea). In: Sfenthourakis S, PB de Araujo, E Hornung, H Schmalfuss, S Taiti \& K Szlávecz (eds) Biology terrestrial isopods: 243-261. Koninklijke Brill NV, Leiden, Germany.

ZIMMER M (2004) The role of woodlice (Isopoda: Oniscidea) in mediating the decomposition of leaf litter. In: Shakir-Hanna SH \& WZA Mikhail (eds) Soil zoology for sustainable development in the 21st century: 285-311. Eigenverlag, Cairo.

ZIMMER M \& W TOPP (1997) Does leaf litter influence population parameters of the common woodlouse, Porcellio scaber (Crustacea: Isopoda)? Biology and Fertility of Soils 24: 435-441.

ZIMMER M \& W TOPP (2000) Species-specific utilization of food sources by sympatric woodlice (Isopoda: Oniscidea). Journal of Animal Ecology 69: 1071-1082. 
